\title{
Metalaxyl Resistance of Phytophthora palmivora Causing Durian Diseases in Thailand
}

\author{
Pornprapa Kongtragoul ${ }^{1, *}$, Koichiro Ishikawa ${ }^{2}$ and Hideo Ishii ${ }^{2,3}$ (D) \\ 1 Department of Agricultural Technology, King Mongkut's Institute of Technology Ladkrabang, Prince of \\ Chumphon Campus, Chumphon 86160, Thailand \\ 2 School of Agriculture, Kibi International University, Minamiawaji 656-0484, Japan; fgiok777@gmail.com (K.I.); \\ hi481204@yahoo.co.jp (H.I.) \\ 3 Faculty of Life and Environmental Sciences, University of Tsukuba, Tsukuba 305-8572, Japan \\ * Correspondence: pornprapa.ko@kmitl.ac.th
}

check for updates

Citation: Kongtragoul, P.; Ishikawa, K.; Ishii, H. Metalaxyl Resistance of Phytophthora palmivora Causing Durian Diseases in Thailand. Horticulturae 2021, 7, 375. https://doi.org/10.3390/ horticulturae7100375

Academic Editor: Rosário Torres

Received: 5 September 2021

Accepted: 26 September 2021

Published: 8 October 2021

Publisher's Note: MDPI stays neutral with regard to jurisdictional claims in published maps and institutional affiliations.

Copyright: (C) 2021 by the authors. Licensee MDPI, Basel, Switzerland. This article is an open access article distributed under the terms and conditions of the Creative Commons Attribution (CC BY) license (https:/ / creativecommons.org/licenses/by/ $4.0 /)$.

\begin{abstract}
Thailand is the leading producer and exporter of durians worldwide. Serious diseases in durians include root rot, stem rot, and fruit rot, which are caused by Phytophthora palmivora, P. nicotianae, and Pythium cucurbitacearum, respectively. Thai farmers have applied fungicides for more than 20 years to control rot, but it remains difficult to control. Thus, the monitoring of fungicideresistance development in pathogens is important for disease management. Pathogens were isolated from naturally infected durians between 2016 and 2017 in southern Thailand. The sequences of the internal transcribed spacer (ITS) and 5.8S regions of rDNA were used for the identification of their species. Seventeen out of twenty isolates were confirmed to be P. palmivora. All the isolates were tested for mycelium-growth sensitivity to metalaxyl, azoxystrobin, and dimethomorph. The results showed that nine isolates were resistant to metalaxyl with the $50 \%$ effective concentration $\left(\mathrm{EC}_{50}\right)$ higher than $100 \mathrm{mg} \mathrm{L}^{-1}$. By contrast, all the isolates were sensitive to both azoxystrobin and dimethomorph, with $\mathrm{EC}_{50}<1 \mathrm{mg} \mathrm{L}^{-1}$. Metalaxyl-resistant isolates were not controlled $(-25.6 \%$ to $22.2 \%$ ) by the treatment of the detached leaves of 'Monthong' durian with $100 \mathrm{mg} \mathrm{L}^{-1}$ metalaxyl prior to inoculation, but all the metalaxyl-sensitive and moderately metalaxyl-resistant isolates were better controlled (33.0\% to $62.6 \%$ ). These results clearly indicate that metalaxyl-resistant strains are present in the populations of P. palmivora in Thailand.
\end{abstract}

Keywords: azoxystrobin; dimethomorph; fungicide resistance; metalaxyl; oomycete pathogen; Phytophthora

\section{Introduction}

The durian (Durio zibethinus), known as the "king of Thai fruits", is one of the most popular fruits in the region and thus attracts a premium price. Thailand is the leading producer of durians, producing $95 \%$ of the world's supply, and was the largest exporter in 2016, with 402,700 tons [1]. Eighty percent of the durians in Thailand are an important export commodity [2-4]. However, root rot, stem rot, and fruit rot diseases, which have been shown to be caused by several Phytophthora species, including P. palmivora, P. nicotianae, and Pythium cucurbitacearum, are the key limiting factors for durian production $[5,6]$. They are serious pathogens because the crop losses and control costs are estimated to be in the range of $20-25 \%$ of production [5]. In regions with high rainfall, such as southern Thailand, durians grow in an environment that is conducive to outbreaks of Phytophthora diseases $[5,7,8]$. Fruit infection commonly occurs in orchards, usually resulting in serious decay and a 10-25\% loss of durian fruits after harvest or during transport to a market [5]. Oomycete fungicides have been used extensively for controlling crop losses. There was an increase in the imports of fungicides from approximately 10,988 tons (154 million USD) in 2014 to approximately 21,004 tons (687 million USD) in 2018 [9,10]. Various fungicide groups, such as phenylamides (PAs), quinone outside inhibitors (QoIs), and carboxylic 
acid amides (CAAs), can be applied to control these pathogens. These fungicides are sprayed more than 20 times per year during the pre-harvest period [10]. In southern Thailand, durian farmers have used PAs, particularly metalaxyl, more widely than QoIs and CAAs. Although these fungicides effectively suppress and control diseases, their longterm use may lead to the development of pathogen resistance, which may significantly reduce their effectiveness. The increase in fungicide-resistant strains in the pathogen populations has been resulting in serious economic problems for farmers [11-13]. The incidence of fungicide resistance in the field has become an important factor limiting the efficacy of disease-control strategies. Spending on fungicides has also increased because few farmers know that fungicide-resistant strains exist, meaning that they still use the same fungicides [14]. Furthermore, the production costs for crops have increased as growers apply fungicides at higher dosages and greater frequency than before. The side effects of fungicides may come with risks, such as serious hazards to humans and the environment.

Fungicide-resistant Phytophthora strains have been reported in many countries, such as the United Kingdom [15], Cameroon [16], China [17], Estonia [18], Mexico [19,20], Morocco [21], Poland [22], Russia [23], Uganda [24], and the United States [25-28]. The Fungicide Resistance Action Committee (https: / / www.frac.info / (accessed on 10 January 2019)) in 2018 reported field resistance to metalaxyl among Phytophthora species, including P. cactorum, causing crown rot in strawberries; P. capsici, causing stem rot in lima bean pods; P. cinnamomi, causing root rot in avocados; P. erythroseptica, causing pink rot in potatoes; P. infestans, causing late blight in potatoes; P. melonis, causing foot rot in cucurbits; P. nicotianae, causing root rot in ornamentals; and P. porri, causing white tip in leeks [29]. In Thailand, metalaxyl resistance was first reported in $P$. infestans isolates, causing late blight of potatoes in the northern part of the country [30]. It is necessary to monitor the sensitivity of pathogens to fungicides for the effective control of crop disease. Because only limited information on the resistance of Phytophthora spp. to fungicides in Thailand is available, the monitoring of resistance is very important for the development of durian disease-management strategies. The objectives of this research were to (1) collect isolates of Phytophthora spp. from naturally infected trees in durian orchards, (2) analyze their internal transcribed spacer (ITS) and 5.8S regions of rDNA to identify the species, and (3) evaluate their sensitivity to metalaxyl (PA), azoxystrobin (QoI), and dimethomorph (CAA).

\section{Materials and Methods}

\subsection{Pathogen Collection and Fungicides}

Fruit rot and stem rot samples of durian that showed natural infection were collected from commercial durian orchards in Chumphon and Ranong Provinces, southern Thailand. Phytophthora-selective PAR(PH)-V8 medium was prepared as follows: a basal medium (Campbell's ${ }^{\circledR}$ V8 juice, $100 \mathrm{~mL}$; $\mathrm{CaCO}_{3}, 1.5 \mathrm{~g}$; agar, $15 \mathrm{~g}$; and distilled water, $900 \mathrm{~mL}$ ) was cooled to $\sim 50{ }^{\circ} \mathrm{C}$ after sterilization and antibiotics (10 mg of pimaricin, $200 \mathrm{mg}$ of ampicillin, and $10 \mathrm{mg}$ of rifamycin) and fungicides (66.7 $\mathrm{mg}$ of pentachloronitrobenzene and $50 \mathrm{mg}$ of hymexazol) were added (https://fhm.fs.fed.us/sp/sod/misc/culturing species_phytophthora.pdf accessed on 18 January 2020). The tissues from the transplanting procedure, in which the plant tissues between diseased and healthy areas were cut into pieces of approximately $5 \times 5 \mathrm{~mm}$ and surface sterilized by soaking them in $10 \%$ Clorox $^{\circledR}$ solution for 1-2 min, were then rinsed in sterile distilled water, and blotted dry on sterile paper towels. The dried tissues were placed on PAR (PH)-V8 selective medium and incubated at a room temperature (RT) of approximately $28-30{ }^{\circ} \mathrm{C}$. All of the isolates obtained were used in this study (Table 1). To test sensitivity, commercial formulations of the following fungicides were used in the experiments: metalaxyl (a.i. (active ingredient), $25 \%$ ), azoxystrobin (a.i., 25\%), and dimethomorph (a.i., 50\%). 
Table 1. Sources of Phytophthora isolates used in this study.

\begin{tabular}{|c|c|c|c|}
\hline Year of Isolation & Isolate Code & Host Tissue & Location \\
\hline \multirow{9}{*}{2016} & D001 & Fruit & Thale Sap Sub-District, Pathio District, Chumphon. \\
\hline & DS_T024 & Stem & Thale Sap Sub-District, Pathio District, Chumphon. \\
\hline & DF_Z030 & Fruit & Tham Sing Sub-District, Muang Chumphon District, Chumphon. \\
\hline & DS_B032 & Stem & Tham Sing Sub-District, Muang Chumphon District, Chumphon. \\
\hline & DF_M034 & Fruit & Khron Sub-District, Sawi District, Chumphon. \\
\hline & DF_PA01 & Fruit & Pak Chan Sub-District, Kra Buri District, Ranong. \\
\hline & DF_S053 & Fruit & Numcha Sub-District, Sawi District, Chumphon. \\
\hline & DF_S055 & Fruit & Numcha Sub-District, Sawi District, Chumphon. \\
\hline & DF_N014 & Fruit & Thale Sap Sub-District, Pathio District, Chumphon. \\
\hline \multirow{11}{*}{2017} & DF_K012 & Fruit & Numcha Sub-District, Sawi District, Chumphon. \\
\hline & DF_M035 & Fruit & Khron Sub-District, Sawi District, Chumphon. \\
\hline & DF_P027 & Fruit & Thale Sap Sub District, Pathio District, Chumphon. \\
\hline & DF_P075 & Fruit & Thale Sap Sub-District, Pathio District, Chumphon. \\
\hline & DF_PA01/2 & Fruit & Pak Chan Sub-District, Kra Buri District, Ranong. \\
\hline & DF_S065 & Fruit & Numcha Sub-District, Sawi District, Chumphon. \\
\hline & DS_T024/2 & Stem & Thale Sap Sub-District, Pathio District, Chumphon. \\
\hline & DS_T026 & Stem & Thale Sap Sub-District, Pathio District, Chumphon. \\
\hline & DF_M050 & Fruit & Khron Sub-District, Sawi District, Chumphon. \\
\hline & DS_B033 & Stem & Tham Sing Sub-District, Muang Chumphon District, Chumphon. \\
\hline & DF_CH04 & Fruit & Na Kha Sub-District, Lang Suan District, Chumphon. \\
\hline
\end{tabular}

\subsection{DNA Extraction, PCR Amplification, and Sequence Analysis}

To identify the species, isolates of Phytophthora that formed zoosporangia were cultured on potato dextrose agar (PDA) plates at $25^{\circ} \mathrm{C}$, and total DNA was extracted as described by Saitoh et al. [31] with slight modifications [32]. A small piece of agar medium with actively growing mycelium (approximately $1 \mathrm{~cm}^{2}$ in size) was transferred into a $1.5 \mathrm{~mL}$ Eppendorf tube containing $500 \mu \mathrm{L}$ of lysis buffer $(200 \mathrm{mM}$ Tris- $\mathrm{HCl}, 50 \mathrm{mM}$ ethylenediaminetetraacetic acid (EDTA), $200 \mathrm{mM} \mathrm{NaCl}$, and $1 \% n$-lauroylsarcosine sodium salt; $\mathrm{pH}$ 8.0) and homogenized using a plastic pestle and electric drill. The mixture was incubated at room temperature for $10 \mathrm{~min}$ and then centrifuged at $13,000 \mathrm{rpm}$ for $5 \mathrm{~min}$ at $4{ }^{\circ} \mathrm{C}$, and the supernatant $(300 \mu \mathrm{L})$ was transferred to a fresh tube. After mixing the supernatant with $750 \mu \mathrm{L}$ of ethanol to induce precipitation, the DNA was pelleted by centrifugation at 13,000 rpm for $2 \mathrm{~min}$ at $4{ }^{\circ} \mathrm{C}$. The pellet was washed with $70 \%$ ethanol, air-dried in a laminar air flow bench and dissolved in $50 \mu \mathrm{L}$ of Tris-EDTA (TE) buffer containing $10 \mathrm{mM}$ Tris- $\mathrm{HCl}$ and $1 \mathrm{mM}$ EDTA ( $\mathrm{pH}$ 8.0). To amplify the rDNA-ITS (ITS1-5.8S-ITS2) regions from total DNA, the PCR primers ITS5 and ITS4 were used [33]. The $50 \mu \mathrm{L}$ PCR mixture contained $1 \mu \mathrm{L}$ of total DNA, a set of forward and reverse primers (a $0.2 \mu \mathrm{M}$ concentration for each) and premixed Go Taq Green Master Mix (Promega, Madison, WI, USA). PCR was performed in a Mastercycler nexus gradient (Eppendorf, Hamburg, Germany) programmed for $1 \mathrm{~min}$ at $94{ }^{\circ} \mathrm{C}$, followed by 35 cycles of $1 \mathrm{~min}$ at $94{ }^{\circ} \mathrm{C}, 1 \mathrm{~min}$ at $52{ }^{\circ} \mathrm{C}, 2 \mathrm{~min}$ at $72{ }^{\circ} \mathrm{C}$, a final extension for $10 \mathrm{~min}$ at $72{ }^{\circ} \mathrm{C}$, and holding at $10^{\circ} \mathrm{C}$. The PCR products were separated by electrophoresis on a $1.5 \%$ agarose gel in $89 \mathrm{mM}$ Tris-borate (pH 8.0) $+2 \mathrm{mM}$ EDTA (TBE) buffer and stained with GelRed ${ }^{\mathrm{TM}}$ (Biotium, Hayward, CA, USA). The PCR products were cleaned using ExoSAP-IT (Affymetrix, Santa Clara, CA, USA) according to the instructions supplied by the manufacturer. Sequencing was conducted at Macrogen Japan Corp. (Kyoto, Japan) using the same primers employed for PCR. After sequencing, the nucleotide sequences were analyzed using the National Center for Biotechnology Information (NCBI)/GenBank database using basic local alignment search tools (BLAST).

\subsection{Fungicide Sensitivity Tests on Culture Medium}

The sensitivities to metalaxyl, azoxystrobin, and dimethomorph of all the tested isolates were assessed using a mycelial growth assay performed on agar culture plates. Mycelial discs, $4 \mathrm{~mm}$ in diameter, were cut from actively growing colony margins and 
transferred upside down onto clarified V8 juice agar amended with $0,0.1,1,10$, and $100 \mathrm{mg} \mathrm{L}^{-1}$ (a.i.) of metalaxyl, dimethomorph, or azoxystrobin with $n$-propyl gallate (PG) at $1 \mathrm{mM}$ as the alternative oxidase (AOX) inhibitor (3 replications). Fungicides were added to the medium after autoclaving, and the plates were incubated at room temperature $\left(28-30^{\circ} \mathrm{C}\right)$. After incubation for 3 days, the colony diameter of the isolates grown on the fungicide-amended and unamended medium was recorded, and the percentage of mycelial growth inhibition by the fungicides was calculated after subtracting $4 \mathrm{~mm}$ from the colony diameter. The growth inhibition (\%) value for each of the fungicide treatments was calculated using the formula given as: [(mean colony diameter on the control medium mean colony diameter on the medium with fungicide)/(mean colony diameter on the control medium) $\times 100]$.

\subsection{Data Analysis for Fungicide Sensitivity}

The values of mycelial growth inhibition (\%) were plotted as probits versus the $\log _{10}$ of the fungicide concentration $\left(\mathrm{mg} \mathrm{L}^{-1}\right)$ and analyzed by linear regression. The regression equation was used to appraise a $50 \%$ effective concentration $\left(\mathrm{EC}_{50}\right)$ for each fungicide's inhibition of the mycelial growth of each isolate. The $\mathrm{EC}_{50}$ values were used to form three categories for sensitivity assays. The isolates with $\mathrm{EC}_{50}$ values $<1 \mathrm{mg} \mathrm{L}^{-1}$ (metalaxyl and dimethomorph) and $<10 \mathrm{mg} \mathrm{L}^{-1}$ (azoxystrobin) were considered sensitive (S); isolates with $\mathrm{EC}_{50}$ values of 1 to $100 \mathrm{mg} \mathrm{L}^{-1}$ (metalaxyl), 1 to $10 \mathrm{mg} \mathrm{L}^{-1}$ (dimethomorph), and 10 to $100 \mathrm{mg} \mathrm{L}^{-1}$ (azoxystrobin) were classified as moderately resistant (MR); and isolates with $\mathrm{EC}_{50}$ values greater than $10 \mathrm{mg} \mathrm{L}^{-1}$ (dimethomorph) and $100 \mathrm{mg} \mathrm{L}^{-1}$ (metalaxyl and azoxystrobin) were considered resistant (R) [34,35].

\subsection{Fungicide Sensitivity Tests on Detached Durian Leaves}

The P. palmivora isolates from each metalaxyl-resistant group, $\mathrm{Met}^{\mathrm{R}}$ (DS_B032, DF_P027, DF_P075, and DF_M050), Met ${ }^{\mathrm{MR}}$ (DF_M034, DF_PA01, DF_N014, and DF_S053), and $\mathrm{Met}^{\mathrm{S}}$ (DF_S055), were selected, and their metalaxyl sensitivity on detached leaves of the durian variety 'Monthong' was determined in vivo. Fifty-four durian leaves were washed thoroughly using sterilized water before being surface sterilized with $10 \%$ Clorox $^{\circledR}$ and air-dried. A wounded inoculation site, with a diameter of $1.5 \mathrm{~mm}$, was marked on the surface of the leaves with a digital Vernier caliper. Each wound (six wounds/leaf) was punctured with a sterile needle. The wounded leaves were soaked in water with and without $100 \mathrm{mg} \mathrm{L}^{-1}$ metalaxyl, the recommended concentration in practice, for $5 \mathrm{~min}$. All the tested isolates were previously cultured on clarified V8 juice agar at $25{ }^{\circ} \mathrm{C}$ for 5 days. The mycelial discs, $5 \mathrm{~mm}$ in diameter, were cut with a sterilized cork borer and transferred upside down to the wounded site of the durian leaves. The inoculated leaves were incubated in a moist plastic box at room temperature. The diameter of the lesion that appeared as brown rot around the wounded site was measured 4 days after incubation, and the percentage of disease control by the fungicide was calculated with the following formula: [(Mean lesion diameter on water treated leaves-Mean lesion diameter on metalaxyl treated leaves)/Mean lesion diameter on water treated leaves] $\times 100$. The experiment was arranged in completely randomized design (CRD) with 3 replications. Data were subjected to Statistix 8 analytical software. Mean of treatment was compared by least significant difference (LSD) at $p \leq 0.05$.

\section{Results}

\subsection{Species Identification by $r D N A$-ITS Sequence Analysis}

A total of 17 out of 20 isolates tested (Table 1) were identified as P. palmivora. In comparison with the sequence of the NCBI accession number KY475630, the identity of the sequences was $97 \%$ to $100 \%$, except for isolate DS_T024, which showed a $95 \%$ alignment with the rDNA-ITS region of $P$. palmivora. The sequences of the ITS segments of the 15 isolates have been deposited in DDBJ under the accession numbers LC510501 to LC510515, respectively (Figure S1). 


\subsection{Fungicide Sensitivity Tests on Culture Medium}

The sensitivity of P. palmivora isolates to metalaxyl, azoxystrobin, and dimethomorph is shown in Table 2. The $\mathrm{EC}_{50}$ values of metalaxyl for the nine isolates were $>100 \mathrm{mg} \mathrm{L}^{-1}$, and these isolates were determined to be metalaxyl-resistant $\left(\mathrm{Met}^{\mathrm{R}}\right)$. The $\mathrm{EC}_{50}$ values of metalaxyl were between 1 and $100 \mathrm{mg} \mathrm{L}^{-1}$ for seven moderately resistant $\left(\mathrm{Met}^{\mathrm{MR}}\right)$ isolates, while four isolates were sensitive $\left(\mathrm{Met}^{\mathrm{S}}\right)$ at $<1 \mathrm{mg} \mathrm{L}^{-1}$. Moreover, all the isolates were sensitive (S) to azoxystrobin in the presence of $\mathrm{PG}$ and dimethomorph, for which the $\mathrm{EC}_{50}$ values were $<1 \mathrm{mg} \mathrm{L}^{-1}$.

Table 2. Sensitivity of Phytophthora isolates to metalaxyl, azoxystrobin, and dimethomorph on clarified V8 juice agar.

\begin{tabular}{|c|c|c|c|c|c|c|c|}
\hline \multirow{2}{*}{$\begin{array}{l}\text { Year of } \\
\text { Isolation }\end{array}$} & \multirow{2}{*}{ Isolate Code } & \multicolumn{3}{|c|}{$\mathrm{EC}_{50}\left(\mathrm{mg} \mathrm{L}^{-1}\right)$} & \multicolumn{3}{|c|}{ Sensitivity Type ${ }^{1}$} \\
\hline & & Metalaxyl & Azoxystrobin & Dimethomorph & Metalaxyl & Azoxystrobin & Dimethomorph \\
\hline \multirow{9}{*}{2016} & D001 & $>100$ & $<0.1$ & 0.3 & $\mathrm{R}$ & $S$ & $S$ \\
\hline & DS_T024 & $>100$ & 0.17 & 0.4 & $\mathrm{R}$ & $S$ & $S$ \\
\hline & DF_Z030 & $<0.1$ & $<0.1$ & 0.3 & $S$ & $S$ & $S$ \\
\hline & DS_B032 & $>100$ & $<0.1$ & 0.3 & $\mathrm{R}$ & $S$ & $S$ \\
\hline & DF_M034 & 2.3 & 0.2 & $<0.1$ & MR & $S$ & $S$ \\
\hline & DF_PA01 & 11.7 & 0.2 & 0.2 & MR & $S$ & $S$ \\
\hline & DF_S053 & 3.9 & 0.1 & 0.1 & MR & $S$ & $\mathrm{~S}$ \\
\hline & DF_S055 & $<0.1$ & 0.3 & $<0.1$ & $\mathrm{~S}$ & S & S \\
\hline & DF_N014 & 1.4 & $<0.1$ & $<0.1$ & MR & S & S \\
\hline \multirow{11}{*}{2017} & DF_K012 & $<0.1$ & $<0.1$ & 0.1 & $S$ & $S$ & $S$ \\
\hline & DF_M035 & 4.9 & $<0.1$ & $<0.1$ & MR & $S$ & $S$ \\
\hline & DF_P027 & $>100$ & $<0.1$ & 0.3 & $\mathrm{R}$ & $S$ & $S$ \\
\hline & DF_P075 & $>100$ & $<0.1$ & 0.3 & $\mathrm{R}$ & S & S \\
\hline & DF_PA01/2 & 5.49 & $<0.1$ & 0.86 & MR & $S$ & $S$ \\
\hline & DF_S065 & 7.86 & $<0.1$ & 0.35 & MR & S & $\mathrm{S}$ \\
\hline & DS_T024/2 & $>100$ & $<0.1$ & 0.37 & $\mathrm{R}$ & $S$ & $S$ \\
\hline & DS_T026 & $>100$ & $<0.1$ & 0.29 & $\mathrm{R}$ & $S$ & $S$ \\
\hline & DF_M050 & $>100$ & $<0.1$ & 0.43 & $\mathrm{R}$ & S & S \\
\hline & DS_B033 & $>100$ & $<0.1$ & 0.35 & $\mathrm{R}$ & $S$ & $S$ \\
\hline & DF_CH04 & $<0.1$ & $<0.1$ & 0.34 & S & S & S \\
\hline
\end{tabular}

${ }^{1} \mathrm{R}=$ resistant, $\mathrm{MR}=$ moderately resistant, $\mathrm{S}=$ sensitive.

\subsection{Fungicide Sensitivity Tests on Detached Durian Leaves}

The inoculation tests confirmed that the $\mathrm{Met}^{\mathrm{R}}, \mathrm{Met}^{\mathrm{MR}}$, and $\mathrm{Met}^{\mathrm{S}}$ isolates of P. palmivora were pathogenic to the durian leaves. Initial symptoms appeared as dark-brown necrotic lesions 2 days after inoculation. Four days after inoculation with $\mathrm{Met}^{\mathrm{R}}, \mathrm{Met}^{\mathrm{MR}}$, and $\mathrm{Met}^{\mathrm{S}}$ isolates, large brown lesions developed on the wounded leaves, regardless of treatment with metalaxyl or water. The mean lesion diameter on the leaves treated with $100 \mathrm{mg} \mathrm{L}^{-1}$ metalaxyl $(11.32 \mathrm{~mm})$ was not significantly different from that in the water controls $(12.32 \mathrm{~mm})$ in the $\mathrm{Met}^{\mathrm{R}}$ group. However, the mean lesion diameters of the $\mathrm{Met}^{\mathrm{MR}}$ and $\mathrm{Met}^{\mathrm{S}}$ groups showed a significant difference between the leaves treated with $100 \mathrm{mg} \mathrm{L}^{-1}$ metalaxyl and water controls. Moreover, the percentage of disease control showed a significant difference between isolates. Metalaxyl showed only $22.2 \%$ disease control at a maximum against the group of $\mathrm{Met}^{\mathrm{R}}$ isolates, which was much less than the $33.0 \%$ to $62.6 \%$ and $61.5 \%$ control against the group of $\mathrm{Met}^{\mathrm{MR}}$ and $\mathrm{Met}^{\mathrm{S}}$ isolates, respectively (Table 3). 
Table 3. Lesion diameters and disease control (\%) on detached leaves after treatment with $100 \mathrm{mg} \mathrm{L}^{-1}$ metalaxyl or water and inoculation with Phytophthora palmivora isolates for 4 days.

\begin{tabular}{|c|c|c|c|c|}
\hline \multirow{2}{*}{ Phenotype ${ }^{1}$} & \multirow{2}{*}{ Isolate Code } & \multicolumn{2}{|c|}{ Mean Lesion Diameter $(\mathrm{mm})^{2}$} & \multirow{2}{*}{$\begin{array}{c}\text { Disease Control } \\
(\%)^{3}\end{array}$} \\
\hline & & Water & $\begin{array}{c}\text { Metalaxyl } \\
100 \mathrm{mg} \mathrm{L}^{-1}\end{array}$ & \\
\hline \multirow{5}{*}{$\operatorname{Met}^{R}$} & DS_B032 & 12.79 & 11.64 & $8.99 \mathrm{c}$ \\
\hline & DF_P027 & 12.41 & 11.41 & $8.06 \mathrm{c}$ \\
\hline & DF_P075 & 16.80 & 13.07 & $22.20 \mathrm{c}$ \\
\hline & DF_M050 & 7.30 & 9.17 & $-25.61 \mathrm{~d}$ \\
\hline & Mean & $12.32 \mathrm{~A}$ & $11.32 \mathrm{~A}$ & \\
\hline \multirow{5}{*}{$\mathrm{Met}^{\mathrm{MR}}$} & DF_M034 & 6.39 & 3.64 & $43.06 \mathrm{~b}$ \\
\hline & DF_PA01 & 12.60 & 4.71 & $62.62 \mathrm{a}$ \\
\hline & DF_N014 & 7.66 & 5.13 & $33.02 \mathrm{bc}$ \\
\hline & DF_S053 & 10.28 & 4.31 & $58.07 \mathrm{ab}$ \\
\hline & Mean & $9.23 \mathrm{~A}$ & $4.44 \mathrm{~B}$ & \\
\hline $\mathrm{Met}^{\mathrm{S}}$ & DF_S055 & $11.33 \mathrm{~A}$ & $4.36 \mathrm{~B}$ & $61.52 \mathrm{a}$ \\
\hline
\end{tabular}

${ }^{1} \mathrm{Met}^{\mathrm{R}}=$ metalaxyl-resistant, Met ${ }^{\mathrm{MR}}=$ moderately metalaxyl-resistant, and $\mathrm{Met}^{\mathrm{S}}=$ metalaxyl-sensitive. $^{2} \mathrm{Mean}^{2}$ lesion diameter of water controls and metalaxyl treatments in each phenotype followed by a distinct uppercase letter was significantly different, with $p=0.05$ or lower. ${ }^{3}$ Disease-control values followed by distinct lowercase letters in the same column were significantly different, with $p=0.05$ or lower.

\section{Discussion}

Phytophthora disease affects the quality and quantity of durians. It has been a major disease for more than 20 years in Thailand. In this study, most of the pathogen isolates collected from the naturally infected 'Monthong' cultivar in commercial orchards in southern Thailand were identified as P. palmivora according to the nucleotide sequences of the rDNA-ITS region. This situation is similar to that in other durian-producing countries such as Australia, Malaysia, the Philippines, Indonesia, and Vietnam, where P. palmivora has been reported to cause diseases $[5,8]$. The analysis of the rDNA-ITS regions was successfully used for the identification of the major species in the genus Phytophthora, including P. palmivora [36]. Phylogenetic relationships among the 50 Phytophthora species were also examined based on their rDNA-ITS sequences [37].

Chemical fungicides are still important for controlling this disease and, hence, maintaining durian production in Thailand. Fungicides are sprayed frequently and in increasing doses. In general, the field recommended rate of metalaxyl, azoxystrobin, and dimetho-

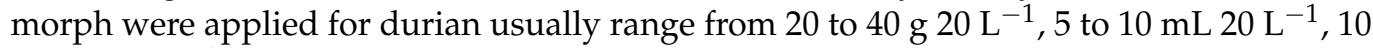

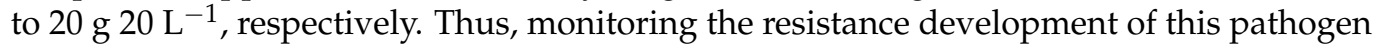
is essential for guiding farmers. In 2016-2017, the majority of the P. palmivora isolates collected from southern Thailand were found to be resistant to metalaxyl but sensitive to azoxystrobin and dimethomorph.

The detection of P. palmivora isolates resistant to metalaxyl indicated that this fungicide might not be effective in controlling Phytophthora diseases in durians. Moreover, Kongtragoul and Viriyaekkul [38] found that Phytophthora spp. caused leaf fall disease in para-rubber but were resistant to metalaxyl in the same area. In the durian orchards of southern Thailand, metalaxyl is sprayed regularly, approximately 2-3 times/month or more often during the rainy season from May to October, which results in the development of resistance to this fungicide. Metalaxyl was sprayed, but the control efficacy was low and resulted in decreased or complete loss of durian yields [38]. In these regions, metalaxyl has been used more frequently than azoxystrobin and dimethomorph in the past, which may explain the higher $\mathrm{EC}_{50}$ values of metalaxyl.

Azoxystrobin and dimethomorph-resistant isolates of $P$. palmivora were not found in this study. Similar research results have been reported for $P$. infestans sensitivity to azoxystrobin and dimethomorph in Russia between 1993 and 2003 [23], Mexico in 2000 [39], and some provinces in China between 2000 and 2008 [17,40]. However, resistance to 
azoxystrobin in P. capsici causing pepper Phytophthora Blight in China [41], and the G143A mutation commonly responsible for high QoI resistance has been found in the cytochrome $b$ gene of resistant isolates [42]. In this case, the resistance frequency was greater than $40 \%$ in the pathogen populations. Therefore, substantial attention needs to be continuously given to prevent or delay the development of fungicide resistance in the management of P. palmivora in durians. Durian growers should reduce the frequency of fungicide applications, mix single-site inhibitors such as QoIs and CAAs with multi-site contact fungicides, and/or rotate with fungicides with different modes of action. The application of metalaxyl should be well-designed to combine with alternate fungicides for disease control in orchards where metalaxyl-resistant strains have already appeared or are widely distributed. Currently, there are several reports on effective fungicides for managing Phytophthora. For example, Ramallo et al. [43] reported that potassium phosphite presents a complex mode of action against the Phytophthora brown rot of lemons in pre- and postharvest applications. Moreover, durian growers should introduce integrated approaches with resistant cultivars, cultural practices, or biological control $[5,44,45]$. We conclude that metalaxyl use should be considered carefully, as it could increase the management costs for durian production in southern Thailand. In contrast, populations of P. palmivora are still sensitive to azoxystrobin and dimethomorph, which suggests that both fungicides can be used in this area for the time being. However, durian growers should use azoxystrobin and dimethomorph carefully because these fungicides also pose the risk of resistance development. Further studies are necessary to monitor the fungicide resistance in a wider range of pathogen populations present in Thailand.

Supplementary Materials: The following are available online at https:/ / www.mdpi.com/article/10 .3390 / horticulturae7100375/s1, Figure S1: Multiple sequence alignments of rDNA-ITS regions in Phytophthora palmivora isolates analyzed in this study.

Author Contributions: Conceptualization, P.K. and H.I.; methodology, P.K., K.I. and H.I.; software, P.K., K.I. and H.I.; validation, P.K., K.I. and H.I.; formal analysis, P.K., K.I. and H.I.; investigation, P.K., K.I. and H.I.; resources, P.K., K.I. and H.I.; data curation, P.K., K.I. and H.I.; writing-original draft preparation, P.K.; writing-review, P.K.; editing, H.I.; visualization, H.I.; supervision, H.I.; project administration, P.K. All authors have read and agreed to the published version of the manuscript.

Funding: This research received no external funding.

Institutional Review Board Statement: Not applicable.

Informed Consent Statement: Not applicable.

Data Availability Statement: Not applicable.

Acknowledgments: The authors express their sincere appreciation of Dusanee Thanaboripat, Sakrin Boonlum, and Wasinee Thamsatit, Faculty of Science, King Mongkut's Institute of Technology Ladkrabang, for supporting this study.

Conflicts of Interest: We declare that there are no conflict of interest.

\section{References}

1. UN Comtrade, Trade Map. Durian Global Market Report 2018. Available online: http:/ /www.plantationsinternational.com/ docs/durian-market.pdf (accessed on 10 January 2019).

2. Chomchalow, N.; Somsri, S.; Na Songkhla, P. Marketing and export of major tropical fruits from Thailand. Assumpt. Univ. J. Technol. 2008, 11, 133-143.

3. Pokterng, S.; Kengpol, A. The Forecasting of Durian Production Quantity for Consumption in Domestic and International Markets. Appl. Sci. Eng. Prog. 2010, 3, 7-18.

4. Parichatnon, S.; Maichum, K.; Peng, K.C. Application of the malmquist productivity index on measurement of productivity trend of durian production in Thailand. Int. J. Bus. Mark. Manag. 2017, 2, 1-9.

5. Drenth, A.; Guest, D.I. Diversity and Management of Phytophthora in Southeast Asia; ACIAR Monograph 114; Australian Centre for International Agricultural Research: Canberra, ACT, Australia, 2004.

6. Suksiri, S.; Laipasu, P.; Soytong, K.; Poeaim, S. Isolation and identification of Phytophthora sp. and Pythium sp. from durian orchard in Chumphon province, Thailand. Int. J. Agric. Technol. 2018, 14, 389-402. 
7. Lim, T.K.; Sangchote, S. Diseases of Tropical Fruit Crops; Tropical Research and Education Center: Homestead, FL, USA, 2003.

8. Abad, R.G.; Cruz, K.J.T. Incidence of Phytophthora fruit rot on four durian cultivars in Davao city, Philippines. Banwa 2012, 9, 1-9. [CrossRef]

9. Office of Agricultural Economics, Department of Agriculture, Thailand. Quantity and Value of Imports of Agricultural Hazardous Substances. Resource Document Office of Agricultural Economics, Department of Agriculture, Thailand, 2018. Available online: http:/ / oldweb.oae.go.th/economicdata/pesticides.html (accessed on 28 September 2019).

10. Department of Agriculture Thailand. Durian Production Technology for Quality. Resource Document. 2018. Available online: http:/ / www.doa.go.th/hrc/chantaburi/images/files/tecno_durian56.pdf (accessed on 10 January 2019).

11. Steffens, J.J.; Pell, E.J.; Tien, M. Mechanisms of fungicide resistance in phytopathogenic fungi. Curr. Opin. Biotechnol. 1996, 7, 348-355. [CrossRef]

12. Deising, H.B.; Reimann, S.; Pascholati, S.F. Mechanisms and significance of fungicide resistance. Braz. J. Microbiol. 2008, 39, 286-295. [CrossRef] [PubMed]

13. Ishii, H.; Hollomon, D.W. Fungicide Resistance in Plant Pathogens: Principles and a Guide to Practical Management; Springer: Tokyo, Japan, 2015.

14. Wightwick, A.; Walters, R.; Allinson, G.; Reichman, S.M.; Menzies, N.W. Environmental risks of fungicides used in horticultural production systems. In Fungicides; Carisse, O., Ed.; InTech: Rijeka, Croatia, 2010; pp. 273-304.

15. Earnshaw, D.M.; Shattock, R.C. Sensitivity of Progeny of Phytophthora infestans to Fungicides. Asian J. Agric. Sci. 2012, 4, $213-224$.

16. Fontem, D.A.; Olanya, O.M.; Tsopmbeng, G.R.; Owona, M.A.P. Pathogenicity and metalaxyl sensitivity of Phytophthora infestans isolates obtained from garden huckleberry, potato, and tomato in Cameroon. J. Crop Prot. 2005, 24, 449-456. [CrossRef]

17. Zhu, G.; Huang, F.; Feng, L.; Qin, B.; Yang, Y.; Hen, Y.; Lu, X. Sensitivities of Phytophthora infestans to metalaxyl, cymoxanil, and dimethomorph. Agric. Sci. China 2008, 7, 831-840. [CrossRef]

18. Runno-Paurson, E.; Fry, W.E.; Remmel, T.; Mänd, M.; Myers, K.L. Phenotypic and genotypic characterisation of Estonian isolates of Phytophthora infestans in 2004-2007. J. Plant Pathol. 2010, 92, 375-384.

19. Matuszak, J.M.; Fernandez-Elquezabel, J.; Gu, W.K.; Villarreal-Gonzalez, M.; Fry, W.E. Sensitivity of Phytophthora infestans populations to metalaxyl in Mexico: Distribution and dynamics. Plant Dis. 1994, 78, 911-916. [CrossRef]

20. Lee, T.Y.; Mizubuti, E.; Fry, W.E. Genetics of metalaxyl resistance in Phytophthora infestans. Fungal Genet. Biol. 1999, 26, 118-130. [CrossRef]

21. Hammi, A.; Msatef, Y.; Bennani, A.; Ismaili, A.E.L.; Serrhini, M.N. Mating type, metalaxyl resistance and aggressiveness of Phytophthora infestans (Mont.) de Bary in Morocco. J. Phytopathol. 2002, 150, 289-291. [CrossRef]

22. Sobkowiak, S.; Śliwka, J.; Chmielarz, R.; Lebecka, R.; Zimnoch-Guzowska, E. Resistance to metalaxyl of Phytophthora infestans isolates occurring in Poland in 2006-2010. Phytopathologia 2016, 61, 29-35.

23. Elansky, S.; Apryshko, V.; Milyutina, D.; Kozlovsky, B. Resistance of Russian strains of Phytophthora infestans to fungicides metalaxyl and dimethomorph. Moscow Univ. Biol. Sci. Bull. 2007, 62, 11-14. [CrossRef]

24. Mukalazi, J.; Adipala, E.; Sengooba, T.; Hakiza, J.J.; Olanya, M.; Kidanemariam, H.M. Metalaxyl resistance, mating types, and pathogenicity of Phytophthora infestans in Uganda. Crop Prot. 2001, 20, 379-388. [CrossRef]

25. Timmer, L.W.; Graham, J.H.; Zitko, S.E. Metalaxyl-resistant isolates of Phytophthora nicotianae: Occurrence, sensitivity, and competitive parasitic ability on citrus. Plant Dis. 1998, 82, 254-261. [CrossRef]

26. Parra, G.; Ristaino, J.B. Resistance to mefenoxam and metalaxyl among field isolates of Phytophthora capsici causing Phytophthora blight of bell pepper. Plant Dis. 2001, 85, 1069-1075. [CrossRef]

27. Taylor, R.J.; Salas, B.; Secor, G.A.; Rivera, V.; Gudmestad, N.C. Sensitivity of North American isolates of Phytophthora erythroseptica and Pythium ultimum to mefenoxam (metalaxyl). Plant Dis. 2002, 86, 797-802. [CrossRef]

28. Peter, R.D.; Sturz, A.V.; Matheson, B.G.; Arsenault, W.J.; Malone, A. Metalaxyl sensitivity of isolates of Phytophthora erythroseptica in Prince Edward Island. Plant Pathol. 2001, 50, 302-309. [CrossRef]

29. Fungicide Resistance Action Committee (FRAC). List of Resistant Pathogenic Organisms Resistant to Disease Control Agents. Resource Document. Fungicide Resistance Action Committee. 2018. Available online: http://www.frac.info/docs/defaultsource/publications /list-of-resistant-plant-pathogens/list-of-resistant-plant-pathogenic-organisms_may-2018.pdf?sfvrsn=a2 454b9a_2 (accessed on 10 January 2019).

30. Chiampiriyakul, P.; Sopee, J.; Mekmok, T. Evaluation of metalaxyl sensitivity among Phytophthora infestans by poisoned food technique using corn agar. In Proceedings of the 49th Kasetsart University Annual Conference, Bangkok, Thailand, 1-4 February 2011; Volume 1, pp. 480-487.

31. Saitoh, K.I.; Togashi, K.; Arie, T.; Teraoka, T. A simple method for a mini-preparation of fungal DNA. J. Gen. Plant Pathol. 2006, 72, 348-350. [CrossRef]

32. Ishii, H.; Zhen, F.; Hu, M.; Li, X.; Schnabel, G. Efficacy of SDHI fungicides, including benzovindiflupyr, against Colletotrichum species. Pest Manag. Sci. 2016, 72, 1844-1853. [CrossRef] [PubMed]

33. White, T.J.; Bruns, T.; Lee, S.; Taylor, J. Amplification and direct sequencing of fungal ribosomal RNA genes for phylogenetics. In PCR Protocols: A Guide to Methods and Applications; Innis, M.A., Gelfand, D.H., Sninsky, J.J., White, T.J., Eds.; Academic Press: New York, NY, USA, 1990; pp. 315-322. 
34. Torres-Calzada, C.; Tapia-Tussell, R.; Higuera-Ciapara, I.; Martin-Me, R.; Nexticapan-Garcez, A.; Perez-Brito, D. Sensitivity of Colletotrichum truncatum to four fungicides and molecular characterization of thiabendazole-resistant isolates. Plant Dis. 2015, 99, 1590-1595. [CrossRef]

35. Tian, M.; Zhao, L.M.; Li, S.; Huang, J.; Sui, Z.; Wen, J.Z.; Li, Y.H. Pathotypes and metalaxyl sensitivity of Phytophthora sojae and their distribution in Heilongjiang, China 2011-2015. J. Gen. Plant Pathol. 2016, 82, 132-141. [CrossRef]

36. Ristaino, J.B.; Madritch, M.; Trout, C.L.; Parra, G. PCR amplification of ribosomal DNA for species identification in the plant pathogen genus. Phytophthora. Appl. Environ. Microbiol. 1998, 64, 948-954. [CrossRef]

37. Cooke, D.E.L.; Drenth, A.; Duncan, J.M.; Wagels, G.; Brasier, C.M. A molecular phylogeny of Phytophthora and related oomycetes. Fungal Genet. Biol. 2000, 30, 17-32. [CrossRef]

38. Kongtragoul, P.; Viriyaekkul, O. Sensitivity detection of Phytophthora spp. causing para-rubber leaf fall disease to same systemic fungicides. In Proceedings of the 2nd International Symposium on Agricultural Technology Global Agriculture Trends for Sustainability, Pattaya, Thailand, 1-3 July 2015; pp. 149-152.

39. Grünwald, N.J.; Sturbaum, A.K.; Romero, M.G.; Garay, S.E.; Lozoya-Saldaña, H.; Fry, W.E. Selection for fungicide resistance within a growing season in field populations of Phytophthora infestans at the center of origin. Phytopathology 2006, 96, 1397-1403. [CrossRef]

40. Sun, H.; Wang, H.; Stammler, G.; Ma, J.; Zhou, M. Baseline sensitivity of populations of Phytophthora capsici from China to three carboxylic acid amide (CAA) fungicides and sequence analysis of cholinephosphotranferases from a CAA-sensitive isolate and CAA-resistant laboratory mutants. J. Phytopathol. 2010, 158, 244-252. [CrossRef]

41. Ma, D.; Jiang, J.; He, L.; Cui, K.; Mu, W.; Liu, F. Detection and characterization of QoI-resistant Phytophthora capsici causing pepper Phytophthora blight in China. Plant Dis. 2018, 102, 1725-1732. [CrossRef]

42. Forcelini, B.B.; Peres, N.A.; Amiri, A.; Seijo, T.E. Resistance in strawberry isolates of Colletotrichum acutatum from Florida to Quinone-outside inhibitor fungicides. Plant Dis. 2016, 100, 2050-2056. [CrossRef]

43. Ramallo, A.C.; Cerioni, L.; Olmedo, G.M.; Volentini, S.I.; Ramallo, J.; Rapisarda, V.A. Control of Phytophthora brown rot of lemons by pre- and postharvest applications of potassium phosphite. Eur. J. Plant Pathol. 2019, 154, 975-982. [CrossRef]

44. Kwon, J.-H.; Won, S.-J.; Moon, J.-H.; Lee, U.; Park, Y.-S.; Maung, C.E.H.; Ajuna, H.B.; Ahn, Y.S. Bacillus licheniformis PR2 controls fungal diseases and increases production of jujube fruit under field conditions. Horticulturae 2021, 7, 49. [CrossRef]

45. Oszust, K.; Pylak, M.; Frac, M. Trichoderma-based biopreparation with prebiotics supplementation for the naturalization of raspberry plant rhizosphere. Int. J. Mol. Sci. 2021, 22, 6356. [CrossRef] 